\title{
ASSESSING THE EFFECT OF CORPORATE GOVERNANCE ON THE NET PROFIT MARGIN OF MANUFACTURING COMPANIES: EVIDENCE FROM NIGERIA
}

\author{
UMAR, Abbas Ibrahim, Ph.D.; SULE YAKUBU \\ Department of Business Administration, Nile University of Nigeria \\ DOI: 10.46609/IJSSER.2020.v05i01.016 URL: https://doi.org/10.46609/IJSSER.2020.v05i01.016
}

\begin{abstract}
The study investigates the effect of Board Size (BS), Board Composition (BC) and Audit Committee Size (ACS) on the Net Profit Margin (NPM) of consumer goods of Manufacturing Companies in Nigeria. The study used ex-post facto research design. The population of this study comprises of all the quoted consumer goods of Manufacturing Companies in Nigeria. Purposive sampling is used by selecting ten quoted consumer goods manufacturing companies from the total of the consumer goods manufacturing companies in the Nigeria Stock Market list. The study collected data from company's financial statement. Descriptive statistics and Panel regression were used for analysis and the findings showed that board composition and audit committee has positive and significant effect on the profit margin of board composition has positive effect on the profit margin of quoted consumer goods Manufacturing Companies in Nigeria. Also, board size has positive and insignificant effect on the board composition has positive effect on the profit margin of quoted consumer goods Manufacturing Companies in Nigeria. The study recommended that he consumer goods manufacturing companies in Nigeria should focus more on their respective operational activities rather than board size since it is insignificant to achieved effective net profit margin and they should also concentrate more on board composition for better net profit margin.
\end{abstract}

Keywords: Board size, Board composition, Audit committee, Net profit margin

\subsection{INTRODUCTION}

The importance of manufacturing companies in an economy can never be overemphasized and the corporate governance mechanism as well as the resultant Net Profit Margin of these companies cannot be neglected. Manufacturing is the path to development, the most important of 


\section{International Journal of Social Science and Economic Research}

ISSN: $2455-8834$

Volume: 05, Issue: 01 "January 2020"

economic growth, it creates jobs, and global trade is based on goods not really services because services are dependent upon manufactured goods. This informed the choice of this study, to ascertain the effect of corporate governance on the net profit margin of this sector of the economy. The recently publicized cases of accounting misadventure of renowned corporations like Enron, World Com, Global Crossing and other companies in the global space have greatly shaken investors ${ }^{e e}$ confidence in the integrity of their corporate financial performance. In Nigeria, the petroleum industry, where the auditors of Africa Petroleum (now Forte Plc.) failed to disclose 24billion naira credit facility in the financial statements was unethical and had demonstrated the fragility of professional reputations.

Corporate Governance relates to the legal way and manner in which financial resources available to an organization are judiciously used to achieve the overall corporate objective of an organization (Tukur \& Bilkisu, 2014). It provides the structure through which the objectives of the company are set, and the means of attaining those objectives and monitoring performance are determined. It aimed at creating strong business confidence through adherence of rules and regulation, transparency and accountability and entrepreneurism. Good corporate governance is recognized to influence the quality of financial reporting which in turn has an important impact on investors ${ }^{\text {ee }}$ confidence and organizational performance (Tukur \& Bilkisu, 2014). In order to improve the corporate governance practice of organizations around the world, coupled with the need to reduce corporate failures, abuse of corporate power and dubious accounting practices witnessed in various organizations all over the world, regulators and professional bodies in different countries proposed a system of codes of best governance practices. This is important considering the rate of global financial crisis that have occurred over the last few years. Thus, corporate governance is committed to providing codes of best practices. The manufacturing sector represents an important sector in the growth and development of every nation. It is however necessary for shareholders and other investors to retain confidence in the manufacturing sector. Subsequently, due to the importance of consumer goods manufacturing sector to the development of other sectors of the economy, there is an increased demand for high quality codes of conduct to regulate the activities of organizations such that the issue of good corporate governance practices cannot be overemphasized (Sanusi, 2013 \& Odozi, 2007).

Although there have been numerous number of studies on corporate governance in many countries all over the world. Majority of these studies have been conducted in developed nations (Aggarwal, 2013; Coskun \& Sayilir, 2012; Orazalin, Makarov and Ospanora, 2014; Marashdeh, 2014; Qasim, 2014 \& Rahman, Ibrahim and Ahmed, 2015). However, only a few number of empirical studies on corporate governance and financial performance of firms have been conducted in developing nations (Uwuigbe 2011; Tornyeva and Wereko, 2012; Momoh and Ukpong, 2013; Adekunle and Aghedo, 2014 and Mohan and Marimuthu, 2015). Furthermore, 


\section{International Journal of Social Science and Economic Research}

ISSN: $2455-8834$

Volume: 05, Issue: 01 "January 2020"

the extent of literature review indicate that none of the study has investigated the effect of corporate governance in Nigeria in the consumer goods manufacturing sector, using current data and other combinations of corporate governance mechanisms used in this study. This constitute an important gap in literature taking into account the difference between developed and developing nations (Ojeka and Mukoro, 2011; Uwuigbe, 2011 \& Iyoha and Fagboyede, 2011).

On the other hand, corporate governance has been identified as an important variable in the growth and development of the market economies. First, it is a source of increased access to external financing which could lead to larger investment, higher growth, and greater employment creation. Second it leads to reduction in the cost of capital that is associated with higher firm valuation. Third, it results in better operational performance through better allocation of resources and better management which creates wealth more generally. Fourth, it leads to reduced risk of financial crises which can have large economic and social costs, and finally, improved relationships among stakeholders is expected to promote social and labor relations as well as environmental protection. Hence, the need to know the relationship that exists between corporate governance and the net profit margin of the manufacturing sector of the economy.

\subsection{STATEMENT OF THE PROBLEM.}

Scholars from the empirical studies have studied various aspect of corporate governance and their effect on organizational performance and have established that corporate governance have a significant role on performance of companies in various part of the world. As much as literature reveals that Board composition, Board Size and Audit committee Size have effect on profitability and general performance. However, there is need to establish the extent to which corporate governance affect manufacturing companies in Nigeria. Specifically, this study focused on effect of corporate governance on Net Profit Margin of the consumer goods manufacturing companies in Nigeria. The pedestal of economic growth and development of Nigeria largely hinges upon the growth of the manufacturing companies, hence, the need for this study.

\subsection{Objectives of the Study}

i. To examine the effect of board size on Net Profit Margin of quoted consumer goods Manufacturing Companies in Nigeria.

ii. To determine the effect of board composition on Net Profit Margin of quoted consumer goods Manufacturing Companies in Nigeria

iii. To ascertain the extent to which the audit committee size affects Net Profit Margin of Quoted consumer goods Manufacturing Companies in Nigeria.

\subsection{Research Questions}


International Journal of Social Science and Economic Research

ISSN: 2455-8834

Volume: 05, Issue: 01 "January 2020"

i. Is there any effect of board size on net profit margin of Quoted consumer goods Manufacturing Companies in Nigeria?

ii. To what extent does the board composition affect net profit margin of Quoted consumer goods Manufacturing Companies in Nigeria?

iii. Does the audit committee size affects net profit margin of Quoted consumer goods Manufacturing Companies in Nigeria?

\subsection{Hypotheses}

H1: Board size has no effect on Net Profit Margin of Quoted consumer goods Manufacturing Companies in Nigeria.

H2: Board composition has no significant impact on Net Profit Margin of Quoted consumer goods Manufacturing Companies in Nigeria.

H3: The audit committee size does not affect Net Profit Margin of Quoted consumer goods Manufacturing Companies in Nigeria

\subsection{LITERATURE REVIEW}

\subsection{Concept of Corporate Governance}

Corporate Governance is the system by which business corporations are directed and controlled. The corporate governance structure specifies the distribution of rights and responsibilities among the major stakeholders/participants in the corporation, such as the board, managers, shareholders and even the other stakeholders, and spells out the rules and procedures for making decisions on corporate affairs. By doing this, it also provides the structure through which the company objectives are set, and the means of attaining those objectives and monitoring performance." Organization of Economic Cooperation and Development- OECD (2005). Corporate governance is also the framework within which rules, relationships, systems and processes are controlled (Osundina et al, 2016). Yusuf, Tambaya and Badamasi (2016) see profit as the rallying point of all stakeholders. According to them, performance of the firm guarantees the payment of dividend, interest, wages, and taxes of shareholders, lenders, employees and government respectively. Corporate governance is measure with board size, board composition and audit committee (Yusuf, Tambaya \& Badamasi, 2016).

Board Size is the number of directors that exist on the board which includes the executive and the non-executive directors. The number of directors may vary from country to country and culture to culture (Zabri, Ahmad \& Wah, 2016). Thus, there is no standard board size. Some companies adopt a small board size with the belief that monitoring would be efficient, better and 


\section{International Journal of Social Science and Economic Research}

ISSN: $2455-8834$

Volume: 05, Issue: 01 "January 2020"

faster decision making while some prefer the larger board size with the argument that larger board size will enhance qualitative decisions. Ahmed and Hamdan (2015) results revealed that a number of 12 persons on the board would be effective. Xavier, Shukla, Oduor and Mbabazize (2015) opined that the board size should be 9 in number while Effiok, Effiong and Usoro (2012) result revealed a number of 12 persons on the board but not significant. Odiwo, Chukwuma, and Kifordu (2013) concluded that increase in board size would increase performance.

Board Composition is the ratio of executive directors on the board compared to the number of nonexecutives. The debate had been for either a greater number of executives on the board or lesser. Anthony (2007) supported larger number of executives with his study specifying 58\% of executive directors on board and this was supported by Xavier, et al (2015) that $68 \%$ of executive directors should be on board. Effiok's, et al (2012) work revealed an insignificant result which can be European Journal of Accounting, Auditing and Finance Research Vol.6, No.9, pp.85-98, December 2018 _ Published by European Centre for Research Training and Development UK (www.eajournals.org) 89 Print ISSN: 2053-4086(Print), Online ISSN: 20534094(Online) interpreted to mean that the number of executives or non-executives was irrelevant and it corroborates with Rimon, Aiman and Sandy (2014) specifying insignificant relationship though negatively associated.

Audit Committee as stipulated by Nigerian Companies and Allied Matters Act (CAMA), 1990 should be a 6-member audit committee $(3$ member representing the shareholders and 3 representing the management/directors). According to Thuraisingam (2013), number of members on the committee floats from 2 to 5 directors though not significant with performance. Osundina et al (2016) also discovered a positive relationship but insignificant. Kajola (2008) empirical studies revealed audit committee has an insignificant relationship with performance. In contrast, Narwal and Jindal (2015) result indicated audit committee members has significantly negative impact on profitability.

\section{Concept of Net profit Margin}

Net profit margin represent the firm's ability to translate sales in peso into profits at different stages of measurement. The net profit margin, a measure of overall operating efficiency, incorporates all of the expenses associated with ordinary business activities. The net profit margin measures profitability after consideration of all revenue and expense, including interest, taxes, and non-operating items (Fraser \& Ormiston, 2004).

Net profit margin refers to ratio of net profit after taxes and total selling. Net profit margin (also called net margin or net profit margin percentage) reflects the overall profitability of the company. Net margin tells a company how much out of every sales dollar it gets to keep after 


\section{International Journal of Social Science and Economic Research}

ISSN: $2455-8834$

Volume: 05, Issue: 01 "January 2020"

everything else has been paid for including people, vendors, lenders, the government, and so on. - Business Literacy Institute

\subsection{Theoretical Framework}

This study adopted the Transactional Cost Economics theory that emphases on the application cost or check-and-balance mechanisms in form of internal and external audit controls, information disclosure, independent outside directors, separation of Board chairmanship from CEO, risk analysis, nomination and remuneration committees (Tricker,2012).

\subsection{Empirical Review}

Hülya (2016) investigated the performances of the listed companies in the Corporate Governance Index differ from other companies listed in the Borsa Istanbul-100 Index, and whether there is a relationship between performance and the value of the corporate governance rating for the companies listed in the Corporate Governance Index Financial ratios were used to calculate the performance of companies. The results showed that the companies that are in the corporate governance index have statistically significantly higher return on assets, net profit margin, and return on equity than the ones that are not indexed. Besides, the companies with higher corporate governance rate, have a statistically significantly higher market book value, and return on equity compared to the ones with lower corporate governance rate.

Aon (2016) studied the impact of corporate governance on financial performance of listed companies on Karachi Stock Exchange Pakistan. Data was collected from forty two companies from different sectors like, insurance, banking, investment banking, and sugar industries. Study includes variables like profit margin \& return on equity as a dependent (profitability) and board size, audit committee, annual general meetings \& chief executive office (corporate governance). Using Pooled OLS, the result of the study proved those board size and audit committees have positive relationship with Profit margin and Return on Equity, if any independent variable changes it also stimulus the positively changing impact on Return on Equity (ROE) and Audit Committee (AC).

Dosunmu, Okey and Alwell (2019) investigated the effect of corporate governance on the performance of banks in Nigeria over the period 2012-2016. To achieve the purpose of the study data on corporate governance proxy by board size, executive and non-executive board members, interest rate margin, profit level and Return on Asset (ROA) of 15 deposit banks in Nigeria were sourced from the CBN and the records of the banks and analysed using panel technique. The results indicated that none of the variables that represents corporate governance was significant in explaining changes in the performance of banks. The result also shows that board size and non-executive board members have negative effect on ROA while executive board members 
International Journal of Social Science and Economic Research

ISSN: $2455-8834$

Volume: 05, Issue: 01 "January 2020"

have positive effect on the performance of banks over the period of this study. The implication of this result is that increase in executive members of a bank's board could improve the performance of the bank in Nigeria. Other variables like interest rate margin and profit level were also insignificant in explaining changes in the performance (ROA) of banks. The result further revealed that the effect of corporate governance on banks 'performance differs across the banks in Nigeria.

Adewuyi and Olowookere (2016) impact of corporate governance on firm financial performance. Using a sample of 64 listed non-financial firms for the period 2002 to 2006 , the study is able to capture the impact of the New Code of Corporate Governance released in 2003 on previous findings. Introductory investigations on the Nigerian capital market operations and regulations depict low, but improving, states. Empirically, Panel regression estimates show that board size, audit committee independence and ownership concentration aid performance.

\subsection{METHODOLOGY}

The study adopted ex-post facto research design. The population for this study is quoted consumer goods Manufacturing Companies in Nigeria. Purposive sampling technique was adopted to select ten (10) consumer goods manufacturing companies listed on the Nigerian Stock Exchange market. The companies are Unilever Nigeria Plc, Cadbury Nigeria Plc, Honeywell Flour Mills, NASCON Allied Industries Plc, Nestle Nigeria Plc, P.Z. Cussons Nigeria Plc, Dangote Sugar, ChamsPlc, Nigeria Breweries and Guinness Nigeria Plc. Secondary data derived from the Annual financial statements of the selected companies were used. The period considered for this study is from 2015 to 2018 i.e. Four (4) years. The dependent variable is Net Profit Margin (NPM) while the independent variable of Corporate Governance had Board Size (BS), Board Composition (BC) and Audit Committee Size (ACS) as its indicators.

Table 1: Showing Variables Used, Abbreviation and Measurement

\begin{tabular}{|l|l|l|}
\hline Variable & Abbreviation & Measurement \\
\hline Board Size & BS & $\begin{array}{l}\text { Number of all directors on the } \\
\text { board }\end{array}$ \\
\hline Board Composition & BC & $\begin{array}{l}\text { Female directors / Total number } \\
\text { of } \\
\text { Directors }\end{array}$ \\
\hline Audit Committee Size & ACS & $\begin{array}{l}\text { Number of audit committee } \\
\text { members }\end{array}$ \\
\hline Net Profit Margin & NPM & Profit before tax / Turnover \\
\hline
\end{tabular}


However, panel regression is used for this study given its superiority over pure cross section or pure time series. Verbeek (2004) sets out the framework for panel study as:

$y_{\mathrm{it}}=\alpha+x_{\mathrm{it}} \beta_{\mathrm{it}}+\varepsilon_{\mathrm{it}}$

The model is stated below:

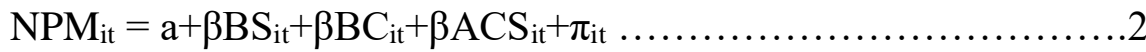

Where NPM $=$ Performance of the $i$ at time it

$\mathrm{BS}_{\mathrm{it}}=$ Board Size of the $\mathrm{i}$ at time it

$\mathrm{BC}_{\mathrm{it}}=$ Board Composition of the $\mathrm{i}$ at time it

$\mathrm{ACS}_{\mathrm{it}}=$ Audit Committee of the $\mathrm{i}$ at time it

$\beta=$ coefficient

$\mathrm{a}=$ constant

$\pi=$ error terms

\section{Hausman Test}

Hausman test is used to decide on most appropriate model to be adopted either between fixed or random effects model. It is believed that the null hypothesis is the preferred model. Random Effect Model is the null hypothesis while the alternative is the fixed effects. It tests whether the unique errors (ui) are correlated with the repressors; the null hypothesis is they are not. That is

Ho $=$ Random Effect

$\mathrm{HA}=$ Fixed Effect

Hausman test uses a statistical distribution chi square with degree of freedom as many as $\mathrm{k}$ where $\mathrm{k}$ is the number of independent variables. If there is a rejection of hypothesis zero where the value of statistics is greater than the critical value (the value of the table chi square) then model fixed effect is used and the reverse is the case where calculated value is less than the critical or table value

In this study, Hausman test is used to test fixed effects model and random effects model (REM).

\section{H0: Random effects model is better than fixed effects model.}


Random effects assume that the entity's error term is not correlated with the predictors which allows for time-invariant variables to play a role as explanatory variables. These characteristics that may or may not influence the predictor needs to be specified.

\section{H1: Fixed effects model is better than random effects model.}

Fixed Effects model explores the relationship between predictor and outcome variables within an entity. Each entity has its own individual characteristics that may or may not influence the predictor variables.

\section{Decision Rules}

Decision Rule: Reject $H 0$ if p-value is less than significance level. Otherwise, do not reject $H 0$.

Decision: Reject $H 0$ since the p-value is less than the significance level of $5 \%$.

\subsection{RESULTS AND ANALYSIS}

Table 2: Descriptive statistics of the Variables

$\begin{array}{lcccc} & \text { NPM } & \text { BS } & \text { BC } & \text { ACS } \\ \text { Mean } & 0.096842 & 10.85000 & 0.202090 & 6.175000 \\ \text { Median } & 0.090400 & 10.00000 & 0.200000 & 6.000000 \\ \text { Maximum } & 0.461100 & 17.00000 & 0.400000 & 9.000000 \\ \text { Minimum } & -2.921000 & 7.000000 & 0.000000 & 5.000000 \\ \text { Std. Dev. } & 0.794380 & 2.684715 & 0.092013 & 0.747217 \\ \text { Skewness } & -3.148862 & 0.661088 & 0.525005 & 1.951561 \\ \text { Kurtosis } & 11.13706 & 2.423578 & 3.288752 & 7.846764 \\ & & & & \\ \text { Jarque-Bera } & 176.4552 & 3.467357 & 1.976501 & 64.54249 \\ \text { Probability } & 0.000000 & 0.176633 & 0.372227 & 0.000000 \\ & & & & \\ \text { Sum } & -3.873700 & 434.0000 & 8.083600 & 247.0000 \\ \text { Sum Sq. Dev. } & 24.61052 & 281.1000 & 0.330190 & 21.77500 \\ & & & & \\ \text { Observations } & 40 & 40 & 40 & 40\end{array}$

Source: E-view, version 9.00 
The mean value of NPM is 0.096 and the median value is 0.09 . This shows the presence of an outlier as can be confirmed the difference between minimum value and maximum value. The mean value of board size is 10.85 and the median value is 10.00 . This shows the presence of an outlier as can be confirmed the difference between minimum value and maximum value. The mean value of board composition is 0.20 and the median value is 0.20 . This shows the presence of an outlier as can be confirmed the difference between minimum value and maximum value. The mean value of audit committee is 6.17 and the median value is 6.00. This shows the presence of an outlier as can be confirmed the difference between minimum value and maximum value.

\section{Table 3: Hausman Test}

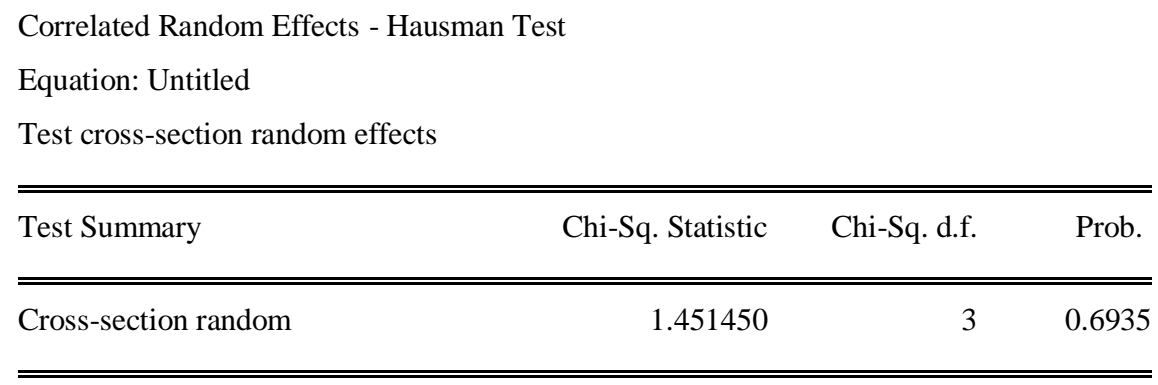

Cross-section random effects test comparisons:

\begin{tabular}{ccccc} 
Variable & Fixed & Random & Var(Diff.) & Prob. \\
\hline \hline BS & 0.009899 & 0.036558 & 0.001765 & 0.5257 \\
BC & 3.450495 & 3.529812 & 1.332035 & 0.9452 \\
ACS & 0.219484 & 0.201359 & 0.000554 & 0.4413 \\
\hline \hline
\end{tabular}

Source: Researcher's Computation Using E-Views 9.0, 2019

The Hausman test indicates that random effect model is the most appropriate to fixed effect model given the probability value of more than 0.05 . Thus, the null hypothesis which states that random effect model is more appropriate is accepted. 
International Journal of Social Science and Economic Research

ISSN: 2455-8834

Volume: 05, Issue: 01 "January 2020"

\section{Table 4: Panel Regression result}

Dependent Variable: NPM

Method: Panel EGLS (Cross-section random effects)

Date: 01/28/20 Time: 13:57

Sample: 20152018

Periods included: 4

Cross-sections included: 10

Total panel (balanced) observations: 40

Swamy and Arora estimator of component variances

\begin{tabular}{ccccc}
\hline \hline Variable & Coefficient & Std. Error & t-Statistic & Prob. \\
\hline \hline C & -2.450230 & 0.933162 & -2.625727 & 0.0126 \\
BS & 0.036558 & 0.055635 & 0.657101 & 0.5153 \\
BC & 3.529812 & 1.582204 & 2.230946 & 0.0320 \\
ACS & 0.201359 & 0.109397 & 1.840633 & 0.0439 \\
& & & & \\
\hline \hline
\end{tabular}

Effects Specification

\begin{tabular}{|c|c|c|c|c|}
\hline & & & S.D. & Rho \\
\hline \multicolumn{3}{|l|}{ Cross-section random } & 0.650841 & 0.6519 \\
\hline \multicolumn{3}{|l|}{ Idiosyncratic random } & 0.475559 & 0.3481 \\
\hline \multicolumn{5}{|c|}{ Weighted Statistics } \\
\hline R-squared & 0.530652 & Mean dependent var & & -0.033232 \\
\hline Adjusted R-squared & 0.466540 & S.D. dependent var & & 0.509583 \\
\hline S.E. of regression & 0.465219 & Sum squared resid & & 7.791430 \\
\hline F-statistic & 3.597620 & Durbin-Watson stat & & 1.913934 \\
\hline Prob(F-statistic) & 0.022636 & & & \\
\hline
\end{tabular}

Unweighted Statistics

\begin{tabular}{lllr}
\hline \hline R-squared & 0.181705 & Mean dependent var & -0.096842 \\
Sum squared resid & 20.13866 & Durbin-Watson stat & 0.740481
\end{tabular}

Source: E-view, version 9.00

Decision rule: $5 \%$ 


\section{International Journal of Social Science and Economic Research}

ISSN: $2455-8834$

Volume: 05, Issue: 01 "January 2020"

The regression result shows that the model is fit for the study since the f-statistics is significant at $5 \%$ level of significance. The result also shows that board size has positive effect on the profit margin of quoted consumer goods Manufacturing Companies in Nigeria while board composition has positive effect on the profit margin of quoted consumer goods Manufacturing Companies in Nigeria while audit committee has positive effect on the profit margin of quoted consumer goods Manufacturing Companies in Nigeria These effects are significant since the Pvalue are less than $5 \%$ but only board size is insignificant since the p-vale is more than $5 \%$. Thus, we concluded that board composition and audit committee has positive and significant effect on the profit margin of board composition has positive effect on the profit margin of quoted consumer goods Manufacturing Companies in Nigeria. Also, board size has positive and insignificant effect on the board composition has positive effect on the profit margin of quoted consumer goods Manufacturing Companies in Nigeria.

The $\mathrm{R}^{2}=0.53$ indicates that only $53 \%$ of variation on corporate governance can be used to explain profit margin of quoted consumer goods Manufacturing Companies in Nigeria but $47 \%$ can be explained by other factors not noted in the regression model which is referred to as error term.

\subsection{DISCUSSION}

The study found out that board composition and audit committee has positive and significant effect on the profit margin of board composition has positive effect on the profit margin of quoted consumer goods Manufacturing Companies in Nigeria. Also, board size has positive and insignificant effect on the board composition has positive effect on the profit margin of quoted consumer goods Manufacturing Companies in Nigeria. The study is in line with the findings of Ano (2016) and Dosunmu et al (2019) who found similar findings on the variables used in this study. The study is also in line with Transactional Cost Economics theory.

\subsection{CONCLUSION}

The study concluded that board composition and audit committee has positive and significant effect on the profit margin of board composition has positive effect on the profit margin of quoted consumer goods Manufacturing Companies in Nigeria. Also, board size has positive and insignificant effect on the board composition has positive effect on the profit margin of quoted consumer goods Manufacturing Companies in Nigeria.

\subsection{RECOMMENDATIONS}




\section{International Journal of Social Science and Economic Research}

ISSN: $2455-8834$

Volume: 05, Issue: 01 "January 2020"

i. The consumer goods manufacturing companies in Nigeria should focus more on their respective operational activities rather than board size since it is insignificant to achieved effective net profit margin.

ii. The consumer goods manufacturing companies in Nigeria should concentrate more on board composition for better net profit margin.

iii. The consumer goods manufacturing companies in Nigeria should focus more audit committee and regulate their activities more since it enhance effective net profit margin in the organizations.

\section{REFERENCES}

Dar, L. A., Naseem, M. A. Rehman, R. U. \&Niazi, G. S. K. (2011). Corporate governance and firm performance: A case study of Pakistan Oil and Gas Companies listed in Karachi Sick Exchange. Global Journal of Management and Business Research, 11(8).

Eklund, Johan \&Palmberg, Johanna \&Wiberg, Daniel, 2009. "Ownership Structure, Board Composition and Investment Performance," Working Paper Series in Economics and Institutions of Innovation 172, Royal Institute of Technology, CESIS - Centre of Excellence for Science and Innovation Studies.

Kajola, S. O. (2008). Corporate governance and firm performance: The case of Nigerian listed firms. European Journal of Economics, Finance and Administrative Sciences.

Lin, J. \& Chiang, M. (2006). Ultimate control and productivity - Evidence from Taiwan's manufacturing firms .retrieved from http://www.efmaefm.org /OEFMAMEETINGS/ EFMA\%20ANNUAL\%20MEETINGS/2008-athens/064.pdf

Nigeria Stock Exchange: Fact book.

Olayiwola, K.T. (2018). The Effect of Corporate Governance on Financial Performance of Listed Companies in Nigeria. European Journal of Accounting, Auditing and Finance Research Vol.6, No.9, pp.85-98,

Jeffrey Coles, Naveen D. Daniel and Lalitha Naveen; Boards: Does one size ... link: https://EconPapers.repec.org/RePEc:eee:jfinec:v:87:y:2008:i:2:p:329-356.

Smith, N.; V. Smith.and M. Verner (2006), "Do women in top management affect firm performance? A panel study of 2,500 Danish firms", International Journal of Performance Management, 55:569-593 
Tricker B. (2012) Corporate Governance: Principles, Policies and Practices ( $2^{\text {nd }}$ ed.) Oxford: Oxford University Press.

Tukur, G \& Bilkisu, A. B (2014), corporate board diversity and financial performance of insurance companies in nigeria: an application of panel data approach, Asian and Economic Review, 4(2), 257-277.

Pathan, Shams \& Faff, Robert, 2013. "Does board structure in banks really ... 37(5), pages 15731589. Handle: RePEc:eee:jbfina:v:37:y:2013:i:5:p:1573-1589

Yang, J. S., \& Krishnan, J. (2005). Audit committees and quarterly earnings management. International journal of auditing, 9(3), 201-219.

Hülya, C.(2016). Corporate Governance and Firm Profitability: Evidence from Turkey. International Journal of Trade, Economics and Finance, 7(6)

Aon, W. A.(2016). Impact of Corporate Governance on Financial Performance: Karachi Stock Exchange, Pakistan. Business and Economic Research, 6(2)

Dosunmu, A. I., Okey, O. \& Alwell, N. (2019). Corporate Governance and Banking Sector Performance in Nigeria. Journal of Applied Economics and Business, 2(2) 33-45

Adewuyi, A. O. \& Olowookere, A. E. (2016). corporate governance and performance of nigerian listed firms: further evidence. Corporate Ownership \& Control, 6(2)

Frase, L., \& Ormiston, A. (2004). Understanding Financial Statements. New Jersey: Pearson Prentice Hall. 